\title{
KINETIKA TRANSPOR FENOL DENGAN ADITIF SURFAKTAN DALAM TEKNIK MEMBRAN CAIR FASA RUAH
}

\author{
Refinel, Emdenis, Djufri Mustafa, Welly Safitri, Yulia Yesti, dan Rudhy Anggi \\ Laboratorium Kimia Fisika Jurusan Kimia FMIPA-Unand \\ Email: nafirefinel21@yahoo.com
}

\begin{abstract}
Study of transport of phenol using the surfactant SDS (Sodium Dodecyl Sulfate), Tween-80 as additive in the source phase and oleic acid, Span-60 additive in the membrane phase with bulk liquid membrane techniques has been performed. Transportation system was in one way using solution of phenol $2.13 \times 10-4 \mathrm{M}$ as the source phase, $30 \mathrm{~mL}$ of chloroform as membrane phase, a solution of $12 \mathrm{~mL}$ of $0.1 \mathrm{M} \mathrm{NaOH}$ as the receiving phase and stirring speed of $340 \mathrm{rpm}$. The concentration of phenol that transported into receiving phase and remaining in the source is determined by measuring phenol method using 4-aminoantipirin and monitored with a spectrophotometer. The result showed the percentage of transport of phenol into the receiving phase is $93.07 \%$ within 120 minutes without any additive surfactant, while for additive oleic acid and Span-60 the percentage of transport phenol is $97.28 \%$ and $88.84 \%$ within 90 minutes. Phenol transport system analyzed by means of a kinetic model involving consecutive irreversible firstorder reaction with the constants exraction of phenol from the source to the membrane $(\mathrm{k} 1)$ of 0.0346 minute $^{-1}, 0.0304 \mathrm{~min}^{-1}$, and from the membrane phase into the receiving phase $(\mathrm{k} 2)$ of $0.0264 \mathrm{~min}^{-1}, 0.0309 \mathrm{~min}^{-1}$ each for additive oleic acid and Span-60 in the membrane phase. Surfactant SDS and Tween-80 additive in the source phase is not effective to decreased the transport time of the phenol in the phase bulk liquid membrane technique.
\end{abstract}

Keysword: Phenol, surfactant, additive, bulk liquid membrane

\section{PENDAHULUAN}

Polutan senyawa organik dan ion logam di lingkungan adalah masalah serius yang banyak dihadapi banyak industri. Ion logam berat tidak biodegradable pada kondisi alami, cenderung terakumulasi dalam organisme hidup yang menyebabkan gangguan dan penyakit. Selain itu, keberadaan ion logam dalam air limbah menghambat biodegradasi polutan organik, yang terdapat dalam limbah cair.

Fenol dan turunannya merupakan senyawa kimia bahan baku industri obat yang termasuk golongan beracun dan berbahaya. Paraaminofenol adalah salah satu senyawa turunan fenol yang merupakan bahan baku obat paracetamol dan obat lainnya. Toksisitas fenol, aniline dan turunan fenol limit batasnya $50 \mathrm{ppb}$ dalam air minim dan air laut ${ }^{[1]}$. Oleh karena itu, kadar fenol dan senyawa turunannya di perairan dan dalam air limbah industri obat yang akan di buang ke perairan harus dikontrol.

Studi untuk menghilangkan dan mengotrol kadar fenol dan turunannya dari air limbah telah banyak dirancang. Penelitian yang telah dilakukan untuk pengolahan air limbah senyawa para-aminofenol adalah dengan lumpur granular pada suhu $30{ }^{\circ} \mathrm{C}$, pengadukan selama 150 hari. Uji biodegradabilitas dilakukan dengan mengukur komposisi hasil gas metananya. Ditemukan bahwa bakteri metanogen dapat menyelesaikan mineralisasi senyawa para-aminofenol ${ }^{[1,2]}$. Metode klisik untuk pemisahan selektif senyawa organik seperti destilasi, fraksionasi, ekstraksi pelarut, dan lain-lain, membutuhkan biaya yang cukup besar.

Membran cair dapat digunakan sebagai alternatif untuk metode pemisahan karena cukup ekonomis, sensitifitas tinggi, dan 
efisien, karena permukaan kontak yang besar untuk transfer masa serta proses ekstraksi dan stripping dalam satu satuan operasi .

Kapasitas membran cair dalam mentranspor suatu analit ditentukan oleh luas permukaan kontak dan tegangan antar fasa (fasa sumber fasa membran) dan (fasa membrane - fasa stripping). Oleh karena itu senyawa surfaktan sangat berperan untuk menurunkan tegangan antar fasa. Dari beberapa jurnal menyatakan bahwa surfaktan memberikan efek terhadap proses pemisahan atau transpor kation dan anion ${ }^{[3,4]}$.

Pada penelitian ini dipelajari pengaruh surfaktan Span 60, asam oleat dan SDS terhadap transpor fenol melalui membran kloroform. Uji yang dilakukan untuk menentukan efektifitas surfaktan terhadap transport fenol adalah dengan menentukan konstanta laju transpor antar fasanya.

Penentuan konstanta transpor antar fasa melalui membran cair fasa ruah terjadi berurutan menurut hukum kinetik reaksi konsekutif irreversibel orde satu ${ }^{[5]}$.

\section{METODOLOGI PENELITIAN}

\section{Alat dan Bahan}

Bahan-bahan kimia yang digunakan antara lain: fenol, kloroform, natrium hidroksida, sodium dodesyl sulfat (SDS), asam oleat, Tween-80 dan Span-60, asam klorida, buffer sitrat $\mathrm{pH} 2$, amonium hidroksida pekat, buffer $\mathrm{pH} \quad 6,8 \quad\left(\mathrm{~K}_{2} \mathrm{HPO} 4\right.$ dan $\left.\mathrm{KH}_{2} \mathrm{PO} 4\right)$, 4aminoantipirin, kalium ferisianida, dan akuades.

Alat-alat yang digunakan dalam penelitian ini antara lain : Spektrofotometer UV/VIS spektronik $20 \mathrm{D}$, sel membran cair fasa ruah, neraca analitik Ainsworth, pH meter 420A, stopwatch, magnetik stirrer dan alat-alat gelas kimia lainnya.

\section{Prosedur Kerja}

\section{Penentuan transpor fenol dengan teknik membran cair fasa ruah.}

Proses transpor dilakukan sel membran cair fasa ruah $^{[1]}$. Disiapkan beker gelas $50 \mathrm{~mL}$ (diameter dalam 3,66 cm) dan dimasukkan fasa membran yaitu $30 \mathrm{~mL}$ kloroform. Dalam larutan fasa membran ini dicelupkan sebuah tabung kaca silindris (diameter dalam 2,17 cm) dan dipipetkan ke dalamnya $6 \mathrm{~mL}$ larutan fasa sumber berupa fenol $2,13 \times 10^{-4} \mathrm{M}$ dengan $\mathrm{pH}$ 2 dimana fenol ini mengandung Tween-80 sebagai surfaktan. Di luar tabung gelas dipipetkan $12 \mathrm{~mL}$ fasa penerima $\mathrm{NaOH} \mathrm{0,2} \mathrm{M}$. Teknis operasi dilakukan melalui pengadukan dengan memakai magnetik stirer pada kecepatan 340 selama 1 jam. Setelah pendiaman 15 menit, fasa penerima dan fasa sumber diambil untuk diukur jumlah konsentrasi fenol yang terkandung di dalamnya dengan menggunakan reagen pewarna 4-amino antipirin dan diukur dengan alat Spektrofotometer UV/Vis.

\section{Penentuan pengaruh surfaktan terhadap transpor fenol}

Pada penentuan pengaruh surfaktan terhadap transpor fenol, dilakukan proses transpor fenol dengan aditif surfaktan ke dalam fasa sumber atau ke fasa membran sesuai dengan sifat kelarutan surfaktannya, dengan urutan parameter sebagai berikut :

\section{Penentuan pengaruh konsentrasi surfaktan Tween-80 dan SDS dalam fasa sumber terhadap transfor fenol}

Penentuan transpor fenol diuji terhadap variasi konsentrasi $(0 \mathrm{~s} / \mathrm{d} 6,93) \times 10^{-4} \mathrm{M}$ untuk aditif Tween-80 dan $(0$, s/d 0,584$) \times 10^{-4} \mathrm{M}$ untuk aditif SDS dalam larutan fenol fasa sumber. Kemudian dilakukan transpor laruran fenol fasa sumber ke fasa penerima dalam sel membran cair. Tween-80 dan SDS dengan konsentrasinya tertentu yang dapat mentranspor fenol optimal digunakan untuk uji laju dan tetapan transpor fenol. 
Penentuan Pengaruh konsentrasi surfaktan asam oleat dan Span-60 dalam fasa membran terhadap transpor fenol

Pentuan transpor fenol diuji terhadap variasi konsentrasi $(0 \mathrm{~s} / \mathrm{d} 6,3) \times 10^{-4} \mathrm{M}$ untuk aditif surfaktan asam oleat dan $(0 \mathrm{~s} / \mathrm{d} 3,0) \times 10^{-4} \mathrm{M}$ untuk aditif Span-60 di dalam fasa membran. Kemudian dilakukan transpor laruran fenol fasa sumber ke fasa penerima dalam sel membran cair. Asam oleat dan Span-60 dengan konsentrasi tertentu yang dapat mentranspor fenol optimal digunakan untuk uji laju dan tetapan transpor fenol.

Pengaruh lama pengadukan terhadap transpor fenol dari fasa sumber ke fasa penerima

Uji kinetika transpor dilakukan terhadap pengaruh aditif surfaktan di fasa sumber dan di fasa membran pada kondisi konsentrasi optimum transpor fenolnya. Variasi lama pengadukan dari 15 s/d 180 menit. Kemudian dilakukan transpor laruran fenol dari fasa sumber ke fasa penerima dalam sel membran cair. Transpor dilakukan terhadap larutan fenol fasa sumber $\mathrm{pH} 2 \mathrm{ke}$ fasa penerima $\mathrm{NaOH} 0,2$ M.

\section{HASIL DAN PEMBAHASAN}

Kondisi optimal untuk transpor fenol diperoleh, fasa sumber larutan fenol $\mathrm{pH} 2 \mathrm{di}$ transpor melalui fasa membran kloroform ke fasa penerima larutan $\mathrm{NaOH} \mathrm{0,2} \mathrm{M}$ dan waktu lama pengadukan dalam proses transport 2 jam. Fenol berhasil ditranspor sampai ke fasa penerima $94,079 \%$ tanpa aditif surfaktan ${ }^{[1]}$.

\section{Penentuan pengaruh surfaktan terhadap transpor fenol}

Surfaktan adalah zat aditif yang dapat menurunkan tegangan antar fasa yang dapat mempersingkat waktu yang dibutuhkan untuk transpor fenol dari fasa sumber ke fasa penerima $^{[3,4]}$. Pada penelitian ini dipelajari pengaruh aditif surfakatan antara lain, Tween80 , SDS yang berada dalam fasa sumber dan
Span-60, asam oleat yang berada dalam fasa membran. Hasil penelitiannya dapat dilihat dalam Gambar 1. Uji pengaruh surfaktan Tween-80 dan SDS yang ditambahkan ke fasa sumber terhadap transport fenol. Dari gambar terlihat bahwa dengan meningkatnya konsentrasi Tween-80 jumlah fenol yang tersisa di fasa sumber meningkat dan tertranspor ke fasa penerima semakin berkurang. Hal yang sama juga terjadi pada surfaktan SDS, yang mana ke dua surfaktan ini tidak efektif dalam mempercepat proses transport fenol. Oleh sebab itu, untuk surfaktan SDS dan Tween-80 tidak dilanjutkan uji laju atau kinetika transpor fenolnya.

Uji pengaruh surfaktan Span-60 dan asam oleat yang ditambahkan ke dalam fasa membran untuk proses transpor fenol. Pada kurva terlihat dengan meningkatnya konsentrasi Span-60 dan asam oleat, jumlah fenol yang tertranspor ke fasa penerima semangkin meningkat dan yang tersisa di fasa sumber semakin berkurang. Kondisi optimum transpor terjadi pada konsentrasi 3,15 x $10^{-4} \mathrm{M}$ untuk asam oleat dan $4,50 \times 10^{-4} \mathrm{M}$ untuk Span-60. Ini menunjukkan bahwa kedua surfaktan efektif dalam proses transpor fenol maka untuk kedua surfaktan dilakukan penelitian lanjutan yaitu uji laju atau kinetika transpor fenol.

Penentuan pengaruh lama pengadukan terhadap transpor fenol untuk aditif asam oleat dan Span-60 di dalam fasa membran

Pengadukan membantu mempercepat proses difusi maka pada penelitian ini dilakukan uji lama pengadukan untuk proses transpor fenol dari fasa sumber ke fasa penerima. Disamping itu, proses transpor juga dipengaruhi oleh tegangan antarfasa, maka dengan adanya aditif surfaktan tegangan antarfasa akan turun, dan transpor fenol dapat terjadi dengan mudah.

Pengaruh surfaktan asam oleat dan Span-60 terhadap lama waktu transpor fenol, diteliti pada kondisi optimum asam oleat dan Span-60 di dalam fasa membran dengan variasi lama pengadukan (10 menit - 150 menit), hasilnya dapat dilihat dalam Gambar 2 dan 3. 


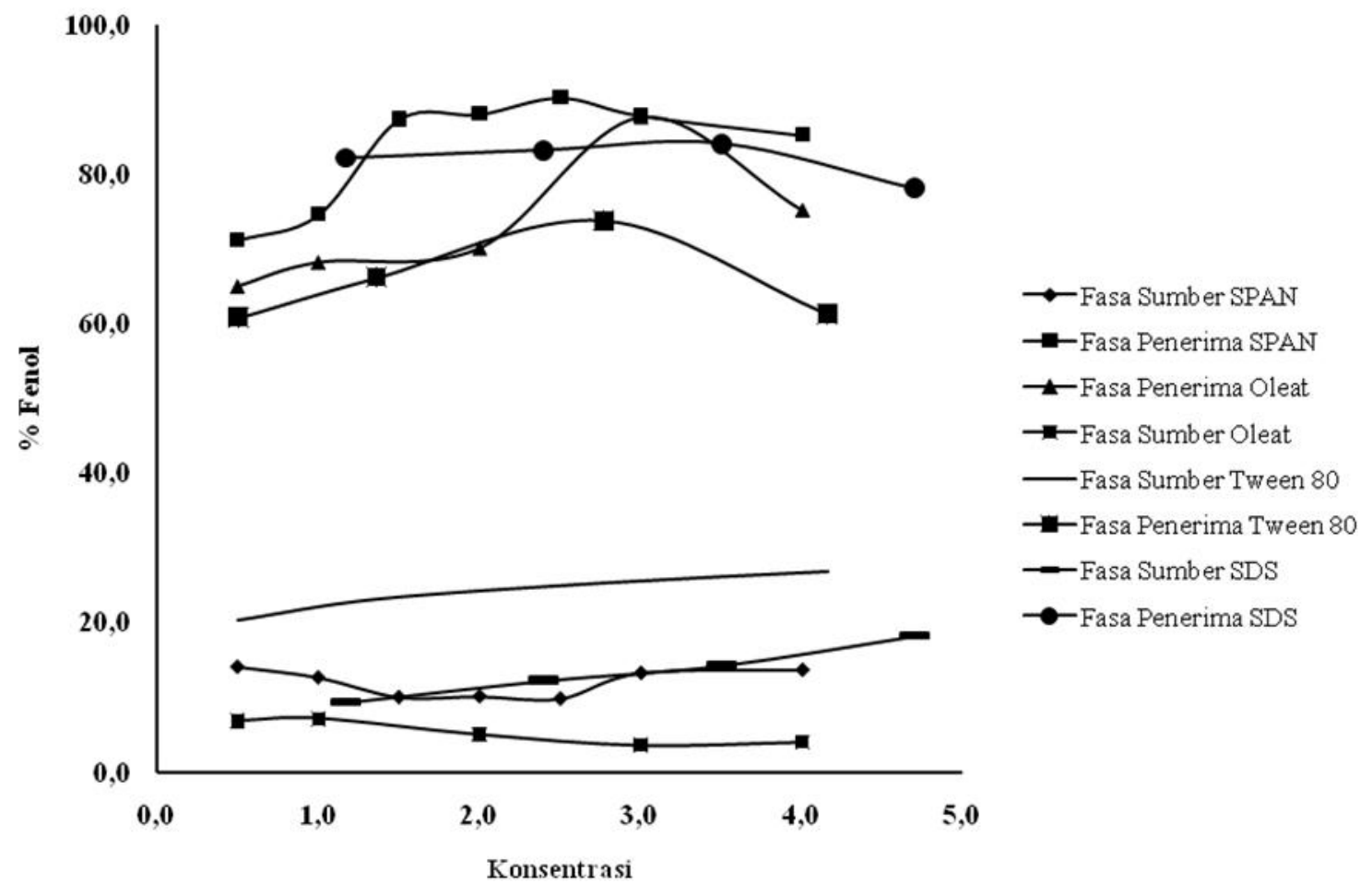

Gambar 1. Penentuan kondisi optimum konsentrasi aditif surfaktan SDS dan Tween-80 di dalam fasa sumber, asam oleat dan Span-60 di dalam fasa membran pada transpor fenol melalui membran kloroform dalam teknik membran cair fasa ruah.

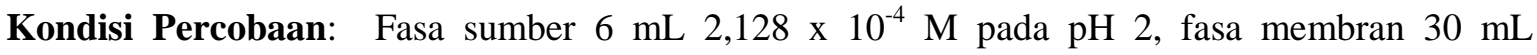
kloroform dan fasa penerima $12 \mathrm{~mL} \mathrm{NaOH} 0,1 \mathrm{M}$, waktu transport 60 menit, kecepatan pengadukan $340 \mathrm{rpm}$, dan waktu kesetimbangan 15 menit.

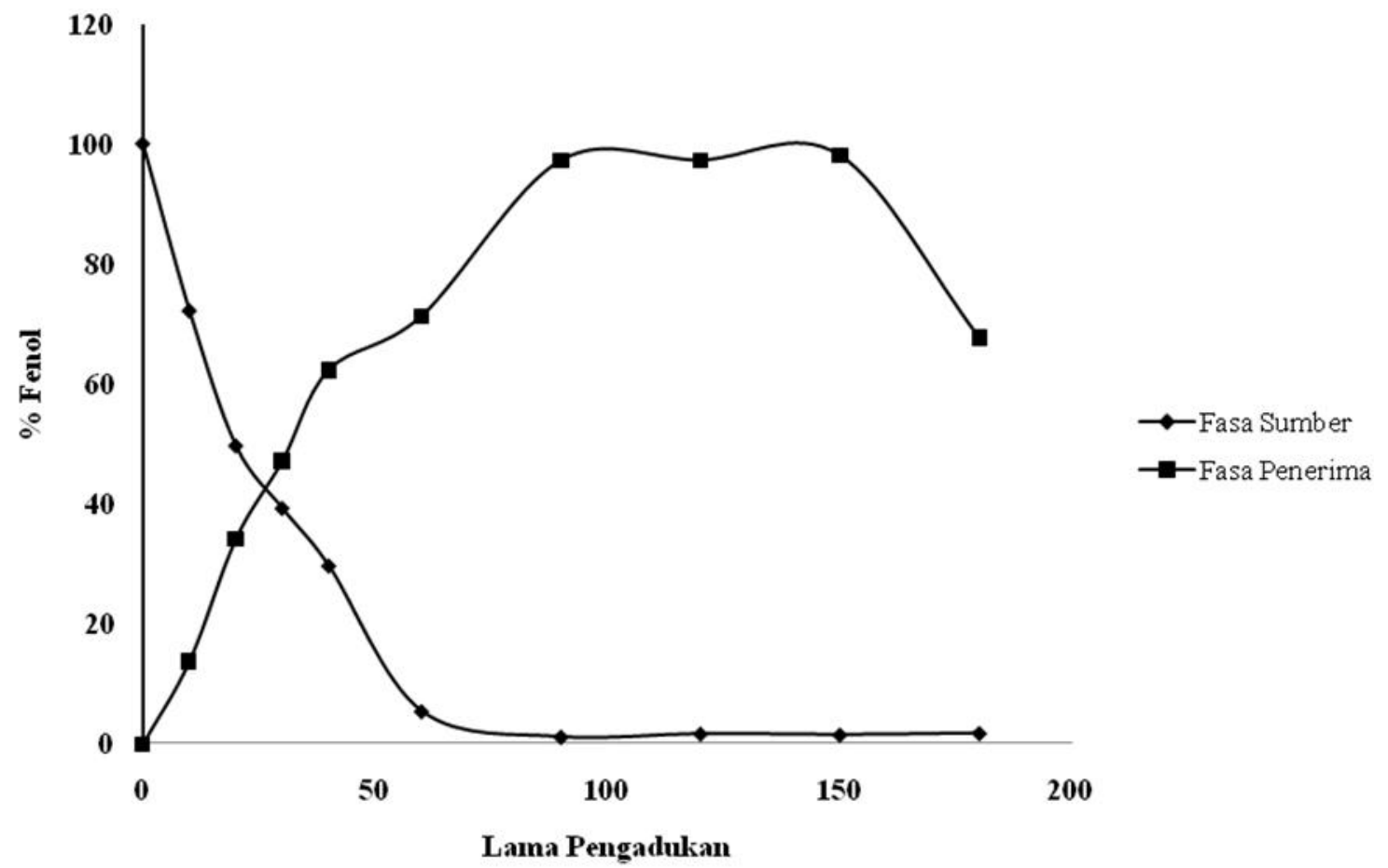

Gambar 2. Pengaruh lama pengadukan terhadap jumlah transpor fenol ke fasa penerima dan fenol sisa dalam fasa sumber menggunakan aditif asam oleat dengan konsentrasi optimum $0,315 \times 10^{-3} \mathrm{M}$ di fasa membran 


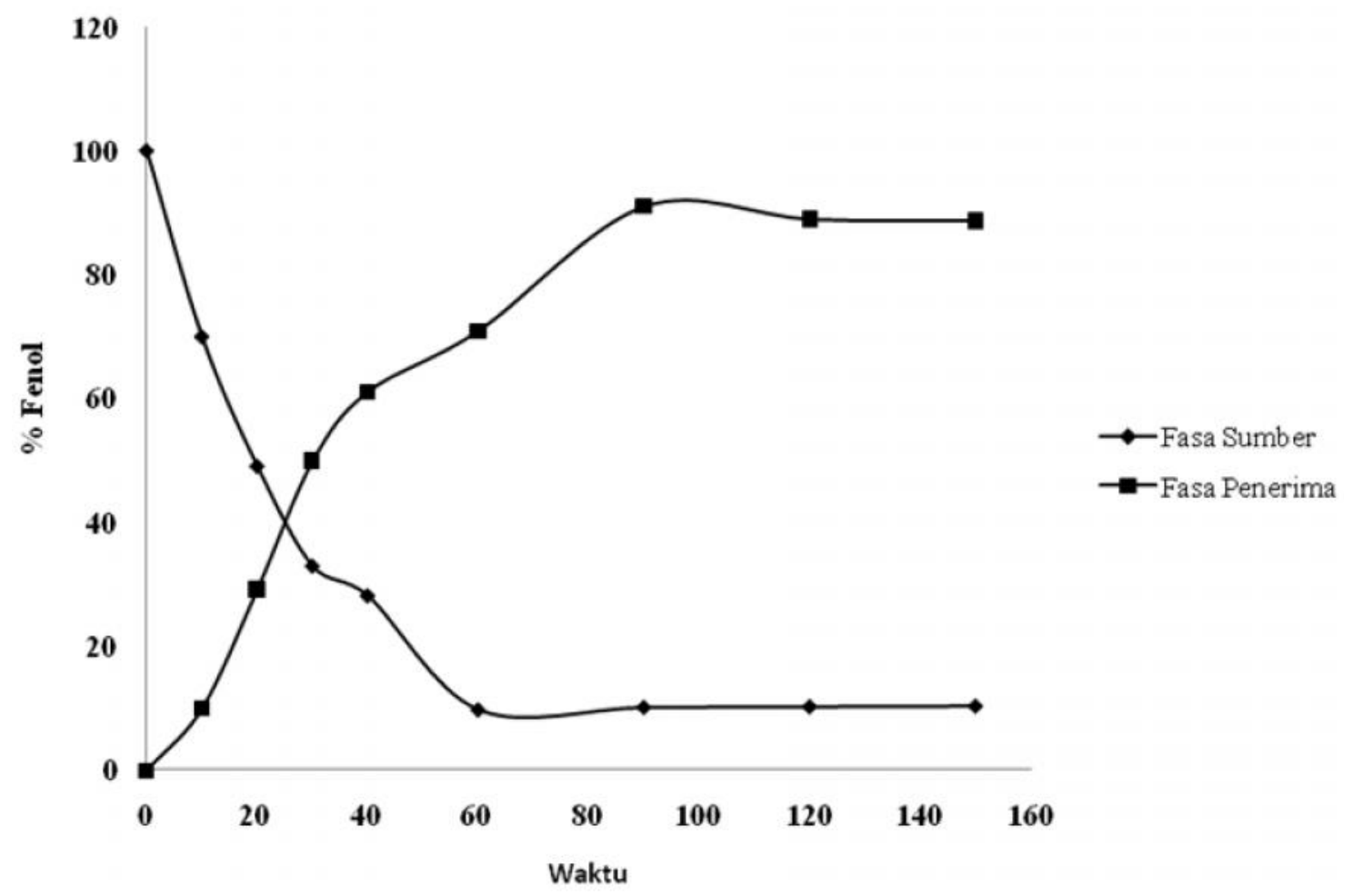

Gambar 3. Pengaruh lama pengadukan terhadap jumlah transpor fenol ke fasa penerima dan fenol sisa dalam fasa sumber menggunakan aditif Span-60 dengan konsentrasi optimum0,25 x $10^{-3} \mathrm{M}$ Span-60 di fasa membran

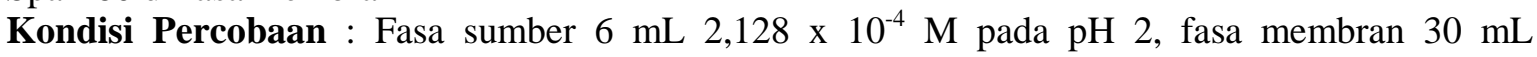
kloroform dan fasa penerima $12 \mathrm{~mL} \mathrm{NaOH} 0,1 \mathrm{M}$, waktu transport 60 menit, kecepatan pengadukan $340 \mathrm{rpm}$, dan waktu kesetimbangan 15 menit.

Dari kurva terlihat bahwa fenol dapat di transport sebanyak $97,28 \%$ dan $88,84 \%$ dalam waktu pengadukan 90 menit dengan adanya aditif asam oleat sebanyak $3,150 \times 10^{-4} \mathrm{M}$ dan Span-60 2,500 $\times 10^{-4}$ M di dalam fasa membran.

Penentuan konstanta kecepatan transpor fenol dengan adanya aditif asam oleat dan span-60 di dalam fasa membran

Pengaruh adanya surfaktan asam oleat dan Span-60 terhadap proses transpor fenol dalam teknik membran cair fasa ruah, gambaran mekanisme dapat dilihat pada Gambar 4 dan 5. Kurva yang menunjukan perubahan perbandingan konsentrasi fenol di dalam fasa sumber (Rs), fasa membran ( $\mathrm{Rm})$, dan fasa penerima (Rp). Dari Gambar 4 terlihat bahwa (Rs) menurun secara mono eksponensial dari 1 sampai 0,099 terhadap waktu transpor 150 menit. Sebaliknya (RP) meningkat secara sigmoid dari 0 sampai 0,877 dalam waktu yang sama, sedangkan $(\mathrm{Rm})$ mencapai maksimum 0,272 pada waktu transpor 20 menit untuk surfaktan Span-60.

Hal yang sama juga terlihat pada pengaruh asam oleat terhadap transpor fenol yaitu dari kurva (Rs) menurun secara mono eksponensial dari 1 sampai 0,014 selama waktu transpor 150 menit, (RP) meningkat secara sigmoid dari 0 ke 0,981 dalam waktu yang sama dan (Rm) mencapai maksimum 0,163 dalam waktu 20 menit.

Kurva dalam Gambar 4 dan 5 mencirikan bahwa proses transpor fenol memenuhi mekanisme reaksi konsekutif irreversible orde pertama. Oleh sebab itu, tetapan laju transpor dapat ditentukan melalui grafik dan perhitungan dari persamaan integral. 


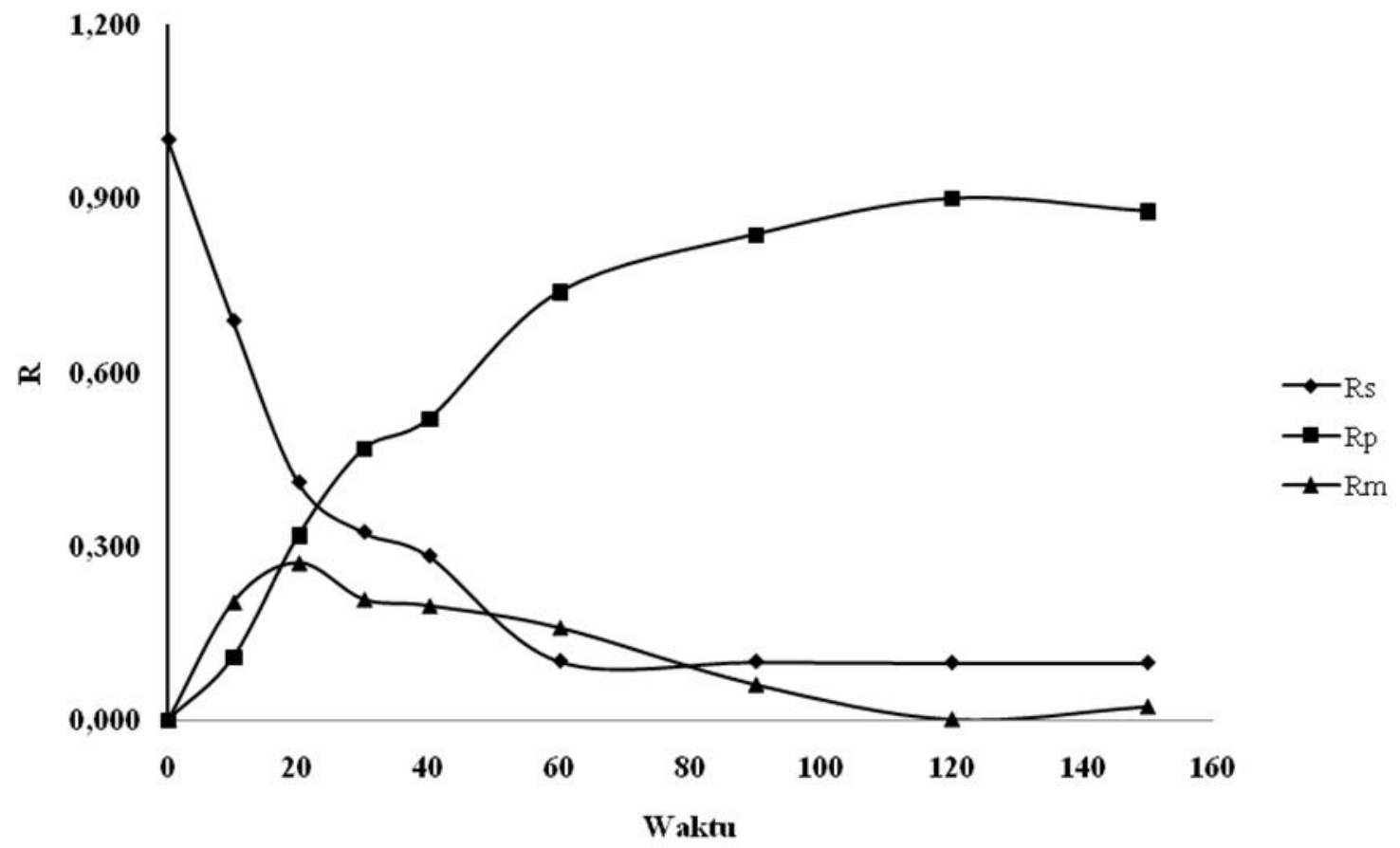

Gambar 4. Perubahan perbandingan konsentrasi fenol di fasa sumber (Rs), fasa membran (Rm) dan fasa penerima $(\mathrm{Rp})$ terhadap waktu, untuk aditif Span-60 di fasa membran

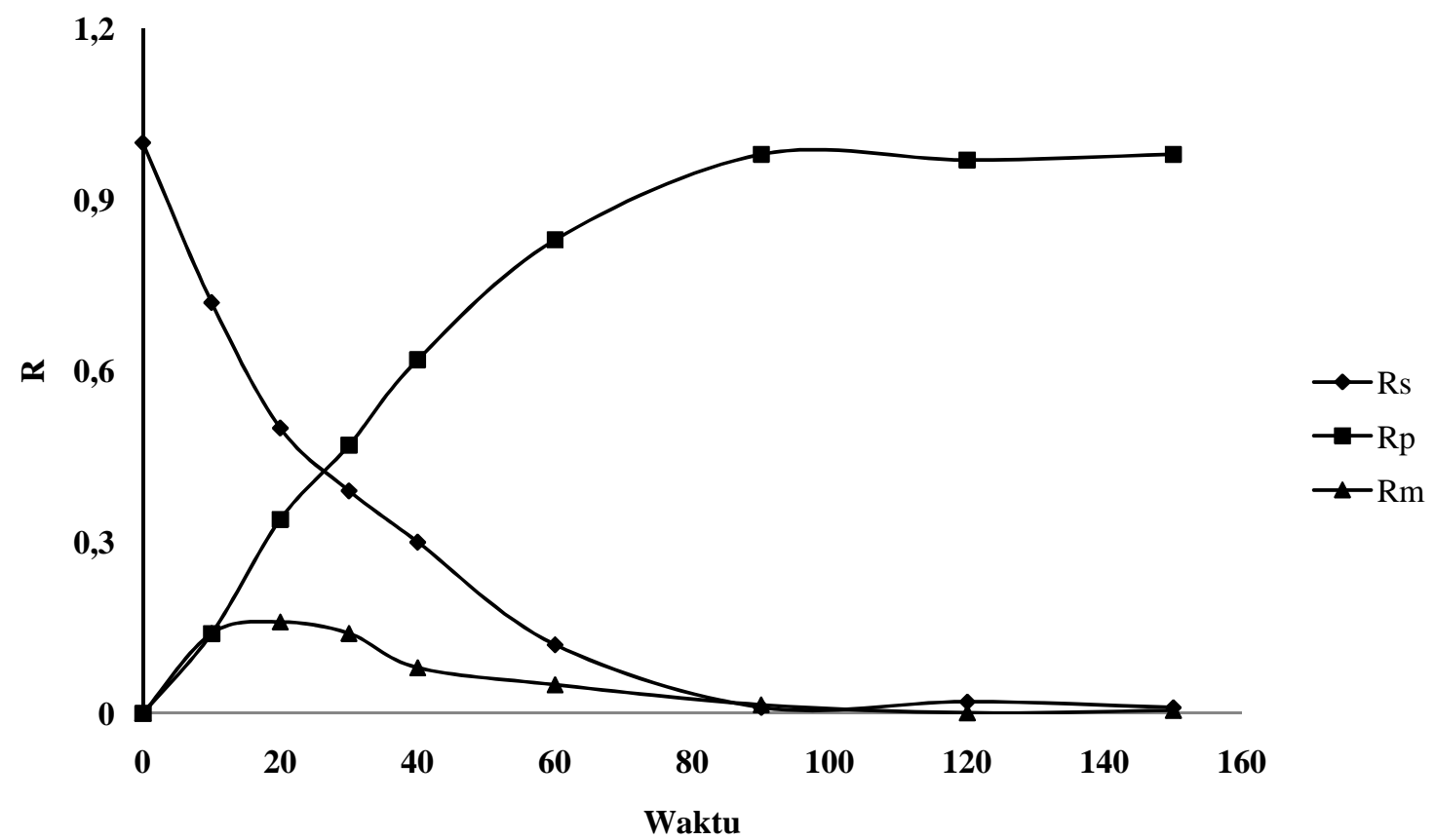

Gambar 5. Perubahan perbandingan konsentrasi fenol di fasa sumber (Rs), fasa membran (Rm) dan fasa penerima (Rp) terhadap waktu, untuk aditif asam oleat di fasa membran

Secara teoritis perubahan perbandingan konsentrasi ion $\mathrm{Cd}(\mathrm{II})$ dalam fasa sumber (Rs), fasa membran $(\mathrm{Rm})$, dan fasa penerima $(\mathrm{Rp})$ memenuhi persamaan :

$$
\begin{array}{r}
R s+R m+R p=1 \\
R s=\frac{C s}{C s_{o}} \\
R m=\frac{C m}{C s_{o}}
\end{array}
$$




$$
R p=\frac{C p}{C s_{o}}
$$

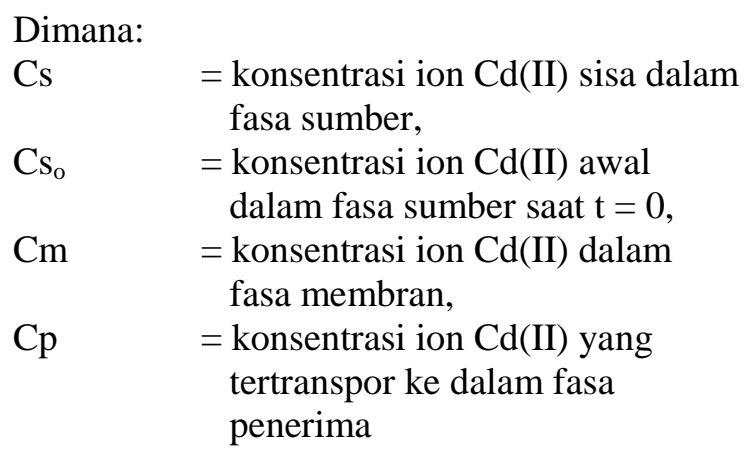

Pada dasarnya, perubahan konsentrasi ion Cd(II) dalam fasa sumber (Rs) menurun secara eksponensial terhadap waktu transpor. Selanjutnya untuk perubahan konsentrasi ion $\mathrm{Cd}$ (II) dalam fasa penerima (Rp) meningkat secara sigmoid, sedangkan $\mathrm{Rm}$ berada dalam suatu keadaan maksimum pada titik tertentu. Hasil ini cenderung menunjukkan bahwa transpor ion $\mathrm{Cd}(\mathrm{II})$ mengikuti hukum kinetik reaksi konsekutif irreversibel orde satu berdasarkan skema kinetik.

$$
\underset{\mathrm{s}}{\mathrm{fenol}} \stackrel{\mathrm{k}_{1}}{\longrightarrow} \underset{\mathrm{m}}{\mathrm{fenol}} \stackrel{\mathrm{k}_{2}}{\longrightarrow} \underset{\mathrm{p}}{\mathrm{Na}(\mathrm{NaOH})}
$$

Dimana $\mathrm{s}, \mathrm{m}$, dan $\mathrm{p}$ adalah fenol dalam fasa sumber, fasa membran, dan fasa penerima. Skema kinetik dapat dijelaskan dengan persamaan :

$$
\begin{gathered}
\frac{d R s}{d t}=-k_{1} x R s=J s \\
\frac{d R p}{d t}=k_{2} x R m=J p \\
\frac{d R m}{d t}=k_{1} x R s-k_{2} x R s
\end{gathered}
$$

Dimana Js, Jp adalah kecepatan pengaliran (fluks) masuk dan keluar dari membran, $\mathrm{k}_{1}$ dan $\mathrm{k}_{2}$ adalah konstanta kecepatan orde satu yang masuk ke dalam membran dan keluar dari membran. Bila $\mathrm{k}_{1} \neq \mathrm{k}_{2}$, hasil integrasi persamaan diatas adalah :

$$
\begin{aligned}
& R s=\exp \left(-k_{1} x t\right) \\
& R p=1-\frac{1}{k_{2}-k_{1}}\left[k_{2} \cdot \exp \left(-k_{1} x t\right)-k_{1} \cdot \exp \left(-k_{2} x t\right)\right] \\
& R m=\frac{k 1}{k_{2}-k_{1}}\left[\exp \left(-k_{1} x t\right)-\exp \left(-k_{2} x t\right)\right] \ldots(8)
\end{aligned}
$$

Dapat dilihat bahwa Rs vs t menghasilkan kurva penurunan eksponensial dimana variasi waktu antara $\mathrm{Rm}$ dan $\mathrm{Rp}$ adalah bieksponensial dan bukan merupakan kurva linear ${ }^{[7]}$.

Keadaan steady state dicapai pada saat $\mathrm{t}=\mathrm{t}_{\max }$, konsentrasi fenol maksimum dalam fasa membran, fluks $\left(\mathrm{J}_{\mathrm{s}}{ }^{\max }\right)$ dan $\left(\mathrm{J}_{\mathrm{p}}{ }^{\max }\right)$ adalah jumlah fenol masuk dan keluar dari membran, besarnya sama tetapi tandanya berlawanan.

$$
J_{s}^{\max }=J_{p}{ }^{\max }
$$

Dan dari konstanta laju masuk dan keluar dari membran dapat ditentukan koefisien transpor masa dengan menggunakan persamaan :

$$
\begin{aligned}
& k_{1}=k_{s} \frac{A_{s}}{V_{s}} \\
& k_{2}=k_{p} \frac{A_{p}}{V_{p}}
\end{aligned}
$$

Dimana $k_{s}, k_{p}$ adalah koefisien transfer masa $(\mathrm{Cm} / \mathrm{s}) . \mathrm{A}_{\mathrm{s}}, \mathrm{A}_{\mathrm{p}}$ adalah daerah antar muka fasa sumber - fasa membran dan fasa membran fasa penerima $\left(\mathrm{Cm}^{2}\right) . \mathrm{V}_{\mathrm{s}}$ dan $\mathrm{V}_{\mathrm{p}}$ adalah volume fasa sumber dan fasa penerima $\left(\mathrm{Cm}^{3}\right)$. Aliran fenol masuk dan keluar dari membran tergantung pada luas daerah antar muka dan volume dari fasa sumber dan fasa penerima $^{[5,6,7]}$.

Nilai tetapan laju berturut-turut adalah untuk $\left(\mathrm{k}_{1}\right)$ dan $\left(\mathrm{k}_{2}\right)$ dapat dihitung dengan menggunakan persamaan 6,7 , dan 8 , hasilnya ditunjukan pada tabel 1 . 
Tabel 1. Konstanta kecepantan transport Fenol dengan keberadaan surfaktan asam oleat dan Span-60 di dalam fasa membran.

\begin{tabular}{lccc}
\hline \multirow{2}{*}{ Surfaktan } & \multicolumn{2}{c}{$\mathrm{k}_{1}\left(\mathrm{menit}^{-1}\right)$} & \\
\cline { 2 - 3 } & Grafik & Integrasi & \\
\hline Asam Oleat & 0,0341 & 0,0346 & 0,0264 \\
Span-60 & 0,0351 & 0,0325 & 0,0309 \\
\hline
\end{tabular}

\section{KESIMPULAN}

Dari hasil penelitian diperoleh fenol dapat ditranspor melalui membran cair fasa ruah kloroform adalah sebanyak $97,28 \%$ dan $88,84 \%$ dengan waktu transpor selama 90 menit dengan adanya aditif surfaktan asam oleat dan Span-60 di fasa membran. Sistem transpor fenol memenuhi hukum kinetika reaksi konsekutif irreversible orde pertama. Konstanta kecepatan transpor fenol dari fasa sumber ke membran $\left(\mathrm{k}_{1}\right)$ yang didapatkan sebesar 0,0346 menit ${ }^{-1}, 0,0325$ menit $^{-1}$, dan dari fasa membran ke fasa penerima $\left(\mathrm{k}_{2}\right)$ sebesar 0,0264 menit ${ }^{-1}$, 0,0309 menit ${ }^{-1}$ masingmasing untuk aditif asam oleat dan Span-60. Surfaktan SDS dan Tween-80 aditif di dalam fasa sumber tidak efektif untuk mempersingkat waktu transpor fenol dari fasa sumber ke fasa penerima dalam teknik membran cair fasa ruah.

\section{DAFTAR PUSTAKA}

1. Wan, Y. Hua, and X. D. Wang, Treatment of high concentration phenolic wastel water by liquid membrane with $\mathrm{N}_{503}$ as mobile carrier, J. Membr. Scie., 135, 263-270, (1997).
2. Refinel, A. Alif, dan A. Setiawan, Optimasi transpor fenol melalui membran cair kloroform dalam teknik fasa ruah, Proseding Seminar HKI di Univ Riau Pekan baru, ISSN : 2086-4310, 393-399, 2011.

3. Valenzuela, et al., Influence of nonionic surfactans compound on coupled transport of copper (II) through a liquid membrane, J. CHil. Chem., 48, (2003).

4. F. Khalid, et al., Separation study of cadmium as cdi $_{4}$ trough a bulk liquid membrane containing ketooconazole and oleic acid, J. Anal. Sci., 21, 501-505, (2005).

5. Refinel, Z. Kahar, dan O. N.Tetra, Kinetika dan selektifitas transpor cu(ii) antara fasa melalui membran cair fasa ruah dengan oksin sebagai zat pembawa, Jurnal Riset Kimia., ISSN : 1978-628X, (4)1 6372, (2010).

6. G. Leon and M. A. Guzman, Facilitated transport of copper (II) through bulk liquid membrane containing difrent carriers : compared kinetic study, Desalination., 223, 330-336, (2007).

7. I. M. Coelhoso, et al., Kinetic of Liquid membrane extraction in system with variable distribution coefficient, $J$. membrane, Sci., 127, 141-152, (2007). 